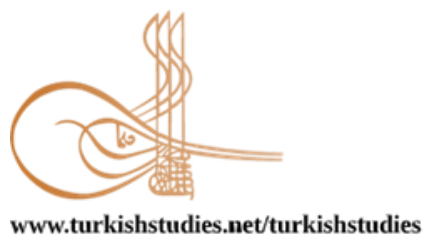

Turkish Studies

\title{
COVID-19 ile İlgili Haberlerde Bilginin Yeniden Üretilmesi Sürecinin İnfodemik Açıdan Analizi
}

\author{
An Infodemic Analysis of Information Reproduction In The News Related to Covid 19
}

\author{
Elif Başak Sarıŏlu* - Erkan Turan**
}

\begin{abstract}
The social panic triggered by the epidemic Covid 19 led to an unprecedented increase in information sharing in the media with an accompanying information pollution. The intensity of the posts by social media users, in particular, has led to an unprecedented communication in this area. It was understood that the news in question, which proceeds as a diffusion, with its source being mostly anonymous and dynamic, is causing collective information pollution. Especially during the onset and rapid spreading of the epidemic, the increase in the share of unrealistic news that may affect the masses of the disease has reached alarming levels. As a result of this, the World Health Organization, one of the most authoritative institutions in Covid-19, stated that the increase in the social media posts produced in connection with the virus mentioned in social media is also remarkable and named this situation as "Infodemia". While fighting against the harmful effects of the virus and the means of its spread in the fight against the disease, the increase in the information we face globally and the information pollution which accompanies it are spreading rapidly all over the world. In our study, within the framework of the concept of infodemia, an analysis of the information flow, which is shared on social media and creates an agenda quickly, whose source is often uncertain and not based on scientific data, was carried out. In this article, first, the news shares that stood out most in the social media are examined. Subsequently, with the survey method applied on 200 people, the awareness of the participants on the concept of infodemia, the effect of infodemic information flow on the participants during the Covid 19 period, and the role of news sharing habits in the spread of infodemic information are examined.
\end{abstract}

Structured Abstract: The virus, which emerged as a new coronovirus in Wuhan, China in early 2020, called Covid 19, has spread all over the world in a short time and changed our habits of life. Due to its high permeability, the virus began to spread rapidly from the exit point, like intertwined rings. The World Health Organization draws more attention to a new danger that has become more evident with this epidemic, while conducting an intense struggle to remove the new threat to the face of humanity. This condition, called Infodemia, is defined as a fast-spreading disinformation. Tedros Adhanom Ghebreyesus, Director of the World Health Organization, is a global misinformation that spreads some of its social media addresses, platforms and

\footnotetext{
* Dr. Öğr. Üyesi, Fenerbahçe Üniversitesi, İletişim Fakültesi Fakülte, Halkla İlişkiler ve Tanıtım Bölümü Asst. Prof., Fenerbahçe University, Communication Faculty, Public Relations and Publicity ORCID 0000-0001-5558-6596

elifsarpca@yahoo.com

** Dr. Öğr. Üyesi, Fenerbahçe Üniversitesi, İletişim Fakültesi, Radyo Televizyon ve Sinema Asst. Prof., Fenerbahçe University, Communication Faculty, Radio Television and Cinema ORCID 0000-0001-8387-240X

erkan.turan@fbu.edu.tr

Cite as/ Atıf: Sarığlu, E. B \& Turan E. (2020). COVID-19 ile ilgili haberlerde bilginin yeniden üretilmesi sürecinin infodemik açıdan analizi. Turkish Studies, 15(6), 819-837. https://dx.doi.org/10.7827/TurkishStudies.44109

Received/Geliș: 09 June/Haziran 2020

Accepted/Kabul: 15 October/Ekim 2020

Copyright $\mathbb{C}$ MDE, Turkey
} 
other mass media, drawing attention to Infodemia at the Security Conference in Munich on February 15 th. (WHO - Munich Security Conference, 2020).

In line with the principles of journalism, the dissemination mechanisms of the information, which is constructed outside the basic journalistic ethics, and this new process, indicate the need for an in-depth analysis in terms of communication science. Journalists and media professionals are the first to come to mind about the creation and dissemination of post-Truth news. According to Kurt Lewin's threshold guards model, the threshold guards, which are located between the source of the news and the target audience, are the sections that determine which news is conveyed and how (Sarığlu, 2020: 394). However, there have been many changes in the media world with the developments in communication technologies. Individuals can easily create and spread their own news. For this reason, while each individual is producing news content or sharing information, they have assumed their own threshold guard duty.

With the emergence and spread of Covid19, it is aimed to investigate the awareness of this issue in our society, especially as the increase in information and news shared on social media and information pollution pose a threat in the fight against the epidemic. The fact that the real, unrealistic or unconfirmed / uncertain news is reflected differently on social media channels (Twitter, Facebook, Instagram etc.) and the fact that the unreal information is entering these channels faster and broader reveals the necessity to investigate the subject from an infodemic perspective. In addition to the literature study, our research is based on the data obtained from the survey conducted with 365 people. In the midst of the global public health crisis with Covid-19, the rapid spread of information, especially on social media platforms, brought with it excessive and unfounded news. This excessive and unfounded information epidemic has begun to complicate the management of the medical outbreak by causing fear and panic in the community. This phenomenon was also named as infodemia, inspired by the concept of pandemic. With the developments occurring after the onset of the Covid-19 outbreak, unrealistic information on the subject has been rapidly circulating (Chakravorti, 2020). After Covid 19 declared it as a global threat to public health by the World Health Organization, a new information platform called Epidemic Information Network (EPI-WIN) was established within the organization. Sylvie Briand, director of the WHO's Health Emergency Program, Communicable Hazards Management, and the architect of WHO's strategy to respond to infrared risk, said that every outbreak will be accompanied by some kind of informational tsunami, and that there will always be unrealistic rumors in this information, He explained that there are phenomena (Zarocostas, 2020). The World Health Organization's office in Geneva has a unit through six regional offices and partners that evaluate false information for 24 hours, investigate rumors that could harm public health, and deny false news with evidence-based information. The WHO organization also struggles with this unreal news from their social media, namely Weibo, Twitter, Facebook, Instagram, LinkedIn, Pinterest and website. While the world continues the disease-fighting aspect of the Covid-19 outbreak, it has also struggled with the reliable information sources that people need, that is, the difficulties in accessing information that can guide them. From the date of occurrence of the pandemic in Turkey administrators delegate to the current state of society and daily reporting of information in order to prevent pollution. However, as in many countries in the world have increased rumors in Turkey from the disease can be prevented with some non-scientific methods and applying those methods such false news is also reflected in the press.

In this study, "awareness of the role of social media in the formation of infodemic knowledge" and "infodemia as a concept" was firstly examined. The survey we have done for my awareness of Infodemia 366 people participated in Turkey. While $48.4 \%$ of the respondents are male, $58.6 \%$ are female. $48.6 \%$ of the people participating in the study are between 45-60 years old, while the predominant segment among the respondents was $26.2 \%$ to $35-45$ years old. One of the most remarkable results of this research is that the social media addressed to the participants should respond to the question of what it means to you at the rate of $51.1 \%$ as "if not". It is noteworthy that in a period when our dependence on social media and especially the technological devices we use the most to reach social media has increased so much, almost half of the participants responded, if not at all. In our daily routine, there are studies on average that we check our mobile phone in 47 minutes a day and click 2617 times (Bankmycell, 2019). How the mobile phone shapes our relationship with the outside world is also reflected in our research on infodemia. It is reflected that the majority of the participants $(97 \%)$ accessed social media via smart phones. In our study, it was understood that although the majority of the participants were university graduates and at a higher education level, the awareness of the concept of infodemia remained limited. It is understood that gender or age is not considered as an important parameter in the spread of infodemic knowledge, but it is believed that the level of education is decisive.

Turkish Studies, 15(6) 
Keywords: Communication, Infodemia, Covid 19, Fake News, Info Pollution, Social Media

Öz: Covid 19 adı verilen salgın hastalığın tetiklediği kamusal panik, medyada daha önce görülmemiş oranda bir bilgi paylaşım artışına ve beraberinde bilgi kirliliğine yol açmıştır. Özellikle sosyal medya kullanıcılarının paylaşımlarındaki yoğunluk, bu alanda eşi benzeri görülmemiş bir iletişimsel etkileşime yol açmıştır. Kaynağı çoğunlukla anonim olan dinamik uzamsam yayılım olarak ilerleyen söz konusu haberlerin, kolektif bir bilgi kirliliğine yol açtığı anlaşılmıştır. Özellikle salgının başlangıç ve hızlı yayılma dönemlerinde, hastalık ile ilgili geniş kitleleri etkileyebilecek gerçek dışı haberlerin paylaşım oranındaki artış endişe verici boyutlara ulaşmıştır. Bunun bir neticesi olarak, Covid-19 konusunda en yetkili kurumlardan biri olan Dünya Sağlık Örgütü, sosyal medyada sözü edilen virüs ile bağlantılı üretilen paylaşımların artışının da dikkat çekici olduğunu belirtmiş ve bu durumu "İnfodemi" olarak adlandırmıştır. Bir yandan hastalık ile mücadelede, virüsün öldürücü etkileri ve yayılım şekilleri gibi tıbbi sorunlar ile savaş sürerken diğer yandan küresel olarak karşı karşıya olduğumuz bilgi artışı ve beraberinde bilgi kirliliği bütün dünyada hızla yayılmaktadır. Çalışmamızda, infodemi kavramı çerçevesinde, sosyal medya üzerinden paylaşılan ve bir anda gündem oluşturan, kaynağı çoğu zaman belirsiz olan ve bilimsel verilere dayanmayan bilgi akışının bir analizi gerçekleştirilmiştir. Araştırma için Fenerbahçe Üniversitesi Akademik Araştırma ve Yayın Eğiti Kurulu'ndan 2020/016 karar sayısı ile yazılı etik kurul izni alınmıştır. Çalışma 366 kişi üzerinde uygulanan anket yöntemiyle, katılımcıların infodemi kavramı konusundaki farkındalığı, Covid 19 döneminde infodemik bilgi akışının katılımcılar üzerindeki etkisi ve infodemik bilginin yayılımında haber paylaşım alışkanlıklarının rolü irdelenmiştir. Çalışmada infodemi kavramının bilinirliğinin sınırlı düzeyde kaldığı görülmüştür. Yalan haberlerin sosyal medya yardımıyla yayılım hızının arttığı ve normleştirildiği gözlemlenmiştir.

Anahtar Kelimeler: İletişim, İnfodemi, Covid-19, Yalan Haber, Bilgi Kirliliği, Sosyal Medya

\section{Giriş}

2020 yılının başlarında Çin'in Vuhan kentinde yeni koronovirüs olarak ortaya çıkan ve Covid 19 olarak adlandırılan virüs, kısa sürede tüm dünyaya yayılarak yaşam alışkanlıklarımızı değiştirmiştir. Yüksek geçirgenlik özelliği nedeniyle virüs, çıkış noktasından dışa doğru iç içe geçmiş halkalar gibi hızla yayılmaya başlamıştır. Dünya Sağlık Örgütü, insanlığın karşısındaki bu yeni tehditi ortadan kaldırmak için yoğun bir mücalede yürütürken, bu salgın ile iyice belirgin hale gelen yeni bir tehlikeye daha dikkat çekmiştir. Infodemi olarak adlandırılan bu durum sanal ortamda hızla yayılan dezenformasyon olarak tanımlanmaktadır. Dünya Sağlık Örgütü Direktörü Tedros Adhanom Ghebreyesus, 15 Şubat'ta Münih'de yapılan Güvenlik Konferansı'nda İnfodemi'ye dikkat çekerek sosyal medya adreslerinden, platformlarından ve diğer kitle iletişim araçlarından hızla yayılan küresel bir yanlış bilgilendirme salgının dünyanın iletişim sağlığı açısından ciddi bir sorun oluşturduğunu açıklamıştır (WHO- Munich Security Conference, 2020).

Habercilik prensipleri doğrultusunda temel gazetecilik etiği dışında kurgulanan bilginin yayılma mekanizmaları ve ortaya çıkan bu yeni süreç, infodeminin iletişim bilimi açısından derinlemesine inceleme gerekliliğine işaret etmektedir. Ekman'a (2009: 38) göre, yalan haber bilginin gizlenme ihtiyacı nedeniyle ortaya çıkabilmekte ve gerçeğin perdelenmesi ile devam etmektedir. Ekman, yalan haberi, yanlış bilgi verme ve doğru olmayan bilginin gerçek gibi sunulmasıdır diye tanımlayarak, tartışmanın temel sorunsalıyla ilgili bir çerçeve ortaya koymuştur. Gerçekdışı haberlerin, sosyal medya ortamlarında hızla yayılımıyla birlikte dijital dünyadaki yansımaları da oldukça kafa karıştırıcı bir hal almıştır. Öyle ki, bazen kişilerin haberlerin doğruluğu konusunda oldukça kararsız kaldığı gözlemlenmektedir. Özellikle sosyal mecralarda yayılan içeriklerde gerçek ve gerçek olmayan bilgiler arasındaki ayrım gittikçe bulanıklaşmıştır (Nielsen \& Graves, 2017). Post-Truth (hakikat ötesi) haberlerin yaratılması ve yayılması konusunda ilk akla gelen kesim gazeteciler ve medya çalışanlarıdır. Kurt Lewin'in eşik bekçileri modeline göre haberin kaynağı ile hedef kitlesi arasında yer alan eşik bekçileri hangi haberin ne şekilde aktarılacağını belirleyen kesimdir (Sarığlu, 2020: 394). Ancak iletişim teknolojilerindeki gelişmeler ile medya 
dünyasında da pek çok değişiklik olmuştur. Bireyler kolaylıkla kendi haberlerini de oluşturabilir ve yayabilir hale gelmiştir. Bu sebeple, her birey haber içeriği üretirken ya da bir bilgiyi paylaşırken bir anlamda kendi eşik bekçiliği görevini üstlenmektedir.

Gerçek dışı haberde yeniden üretim sürecinde, haberin gerçek olmayan başka bilgilerle donatılabileceği ve bu süreçte ilk bilgiden daha farklı bir mesajın ortaya çıkabileceği tartışmanın boyutlarını farklılaştırsa da Goebbels "Büyük Yalan Kuramında" "Söylediğiniz yalanlara inananlar mutlaka olacaktır." sözüyle o bilginin toplum tarafından mutlak bir reddetmeyle karşılanmayacağını, yalanı tekrar ettiğiniz müddetçe zamanla bu bilginin doğruymuş gibi kabul edileceği sonucunu çıkarmıştır (Özarsalan, 2014: 61). Bu noktadan bakıldığında, bir anlamda, post-truth haberlerin çevrim içi dolaşımının artmasıyla gerçek gibi algılanması arasında da bir doğru orantı olabileceği düşünülmektedir. "Post Truth" kavramıyla Keyes (2004: 28-45) yalan haberin üretim sürecinde yanlış bilgiyi oluşturan kaynakları cezalandırılması konusundaki yetersizlikler ya da bu tarz bilgilerin hızla yayılmasında etkili olan sistemlerin önüne geçilmesi için çeşitli yaptırımların olmadığına dikkat çekmektedir. "Homo sapien"lerin yalan söylemeye yeni başlamadığını hatırlamak ve yalan haberin yayılımının da yeni bir olgu olmadığının altını çizmek gerekmektedir. Geçmişten günümüze, siyasetçilerden üniversitedeki akademisyenlere, iş adamlarından doktorlara ve gazetecilere kadar her meslek grubundan ve yaştan bireyin çıkarları uğruna yalan söyleyebildiğine şahit olmuşuzdur. Ancak, post-truth kavramının gündeme gelmesindeki en büyük sebep, bu yalan söyleme durumunun alenileştirilmesi ve hatta sistemin olmazsa olmaz bir parçası haline getirilmesidir (Sarığlu, 2020: 386). Yalan haber gibi dezenformasyon da yeni bir olgu değildir, yeni teknolojinin desteklediği eski bir hikâye olarak tanımlanabilir (Ireton, Posetti, 2018:15). Çalışmada, aşırı ve asılsız bilgi veya haber salgınının, toplumda korku ve paniğe yol açarak, esas salgının yönetimini zorlaştırması olarak bilinen infodemi kavramı konusunda toplumdaki farkındalık incelenmiştir. Araştırma, Türk halkının gerçek dışı haberlere maruz kalmasının yanı sıra kimi zaman iletici rolü de üstlenebildiğini göstermiştir. Görünüşte çelişkili olan bu tablo bize derinlemesine araştırma yapılması gerekliliğini göstermektedir. Uygulanan anket sonucunda elde edilen veriler işlenerek infodemi konusunda Türk halkının farkındalığı, eğilimleri ve tercihleri ortaya konmuştur. Ek olarak haber üreticileri, tüketicileri, taşıyıcıları ve bilgi arasındaki epistemolojik duruma vurgu yapılmıştır.

İnfodemi ile ilgili son dönem çalışmaların Covid-19 temelli olması hiç şaşırtıcı değildir. Zira son dönemde yaşamımızı derinden etkilemesi nedeniyle üzerinde en çok konuşulan konu bu olmuştur. Bu konuda yapılan araştırmalardan Cornell Üniversitesinde Cinelli ve Quattrociocchi vd. tarafindan yürütülen çalışma ön plana çıkmaktadır. Araştırma, Covid-19 hakkındaki bilgilerin yayılımını Twitter, Instagram, YouTube, Reddit ve Gap üzerinden büyük veri analizi yaparak ele almaktadır. Kitlelerin katılımı ve ilgisinin analiz edildiği çalışmada, her platformda kullanıcılar için küresel ölçekte söylemin gelişimi hakkında bir değerlendirme sunulduğu anlaşılmaktadır (Cinelli, Quattrociocchi, Galeazzi, 2020). Bir başka çalışmada da sosyal medya dijital antropoloji açısından ele alınmış ve sosyal medyanın Covid-19 pandemisindeki edindiği rol mercek altına yatırılmıştır. Salgın sonrası oluşan yeni dünya düzeninde ülkelerin digital platformlardaki sorumluluklarına vurgu yapılmıştır (Kırık, Özkoçak, 2020:133-154). Mesquita, Oliveira, Seixas ve Paes' in (2020) çalışmasında tıbbi alandaki sahte haberlerin bir kişiye veya kuruluşa zarar verebilecek kadar yanıltıcı olabildiği ve bazı spesifik gıda, takviye veya tedaviye yönelik yalan haberlerin maddi kar elden etme amaçlı üretildiğinin altına çizilmiştir. Çevrim içi ortamlarda yalan haberlerin önüne geçilmesini umut eden bir yaklaşım sahte haberleri ve yanlış bilgileri tespit etmek için hesaplama yöntemlerine başvurmaktır. Bu alanda kullanılan tekniklerin çoğu yapay zekâ alanında ve esas olarak da NLP (Doğal Dil İşleme) ve Makine Öğrenimi yöntemleri kullanılarak geliştirilmektedir. Bir metnin otomatik olarak sahte içerik olup olmadığının kategorize edilmesi makine öğrenme ve NLP çözümlerinin yanı sıra sosyal bağlam modelleme (Ozbay, Alatas, 2020: 540, Kapusta, Obonya, 2020: 4), bilgi tabanlı sistemler (Shu, Sliva, Wang, Tang, Liu, 2017: 22-36) duyarlıl1k analizleri (Rubin, Chen, Conroy :2015: 1-4) de kullanılarak bir ölçüde yapılabilmektedir. 


\section{Araştırmanın Metodolojisi}

Covid19'un ortaya çıkması ve yayılması ile beraber, özellikle sosyal medyada paylaşılan bilgi ve haberdeki artışın ve bilgi kirliliğinin, salgınla mücadelede tehdit unsuru oluşturması üzerine, toplumumuzda bu konudaki farkındalığın araştırılması hedeflenmiştir. Gerçek, gerçek dışı ya da doğruluğu teyid edilememiş/belirsiz haberlerin sosyal medya mecralarında (Twitter, Facebook, Instagram vs.) farklı şekilde yansıtıldığı ve gerçek dışı bilgilerin bu mecralarda daha hızlı ve daha geniş bir dolaşıma giriyor olması, konunun infodemik açıdan araştırılması gerekliliğini ortaya koymuştur. Araştırma için Fenerbahçe Üniversitesi Akademik Araştırma ve Yayın Etiği Kurulu'ndan 2020/016 karar sayısı ile yazılı etik kurul izni alınmıştır. Çalışmamız literatür incelemesine ek olarak, 365 kişi ile gerçekleştirilen anket uygulamasından elde edilen verilere dayanmaktadır.

\section{3. İnfodemi ve Pandemideki Rolü}

Covid-19 ile birlikte küresel halk sağlığı krizinin ortasında bilginin özellikle sosyal medya platformlarında izlediği hızlı yayılım beraberinde aşırı ve asılsız haberi getirmiştir. Bu aşırı ve asılsız bilgi salgını, toplumda korku ve paniğe yol açarak tıbbi salgının yönetimini zorlaştırmaya başlamıştır. Bu olguya, pandemi kavramından da esinlenerek infodemi adı verilmiştir. Sosyal medya üzerinden genellikle takma isimler kullanan kişiler asılsız bilgilerin çıkış noktasını oluşturmaktadır. Özellikle Covid 19'un ortaya çıkışından itibaren bir bilgi patlamasına tanıklık edilmektedir. Öte yandan, yalan haberin ortaya çıktığı kaynaktan gelen bilgiler toplumu sarmalayan bir haber yı ̆̆ınına dönüşmüştür. Veri ve bilginin fazlalığı, bilgi toplumunun özelliklerinden biri olmakla birlikte, gelinen noktada artık kritik konu, bilgiye erişim noktasından ziyade onu yönlendirme ve yönetmeye doğru kaymaktadır. Web içeriklerinin ve sosyal medyanın bilgiye erişimi kolaylaştırması, bireylerin internet üzerinden etkileşim içerisinde olabilmesi ve sosyal medyada bilgiyi kolayca üretebilmeleri ve yayabilmeleri, bilginin dolaşımını yadsınamaz bir şekilde arttırmıştır (Vicario, Bessi, Zollo vd., 2016: 554-559).

Covid-19 salgının başlamasından sonra ortaya çıkan gelişmelerle birlikte, konu üzerindeki gerçek dışı bilgiler hızla dolaşıma girmiştir (Chakravorti, 2020). Covid 19'un Dünya Sağlık Örgütünce toplum sağllğı için küresel bir tehdit olarak ilan edilmesinin ardından organizasyon bünyesinde Salgın Bilgi Ağ̀ (EPI-WIN) adlı yeni bir bilgi platformu kurulmuştur. DSÖ'nün Sağlık Acil Durumları Programı Bulaşıcı Tehlikeler Yönetimi Direktörü ve DSÖ'nün kızılötesi riske karşı koyma stratejisinin mimarı Sylvie Briand, her salgına bir tür bilgisel tsunamin eşlik edeceğini ve bu bilgiler içinde her zaman gerçek dışı söylentiler olacağını ve Orta Çağ'da bile bu fenomenlerin olduğunu açıklamıştır (Zarocostas, 2020). Dünya Sağlık Örgütü'nün Cenevre'deki ofisinde altı bölge ofisi ve ortakları aracılığıyla 24 saat boyunca yanlış bilgileri değerlendirip toplum sağlığına zarar verebilecek söylentileri araştıran ve yalan haberleri kanıta dayalı bilgilerle yalanlayan bir birim bulunmaktadır. DSÖ Örgütü, kendi sosyal medyalarından yani Weibo, Twitter, Facebook, Instagram, LinkedIn, Pinterest ve web sitesinden bu gerçek dışı haberlerle de mücadele etmektedir. Kullanıcıların tercihlerini ve tutumlarını, algoritmalarını dikkate alarak içerik tanıtımına ve dolayısıyla bilginin yayılmasına aracılık edecek iletişim teknolojilerinin varlığ 1 Facebook, Instagram, Youtube ve Twitter gibi sosyal medya platformları benzeri görülmemiş miktarda içerik ve söylentileri artırabilir. Bu paradigma değişimi, toplumsal algıların inşasını derinden etkilemektedir (Kulshrestha, Eslami, Messias vd., 2017, 417-432).

Dünya, Covid 19 salgınının hastalık ile mücadele yönünü sürdürürken eş zamanlı olarak insanların ihtiyaç duydukları güvenilir bilgi kaynakları yani onlara rehberlik edebilecek bilgiye ulaşım zorlukları ile de mücadele içine girmiştir. Salgının tıbbi zorluklarının yanında yaşadığımız bu infodemi durumu, genellikle kaygı, güvensizlik, stres gibi psikolojik, hatta bazı durumlarda ise fizyolojik sorunlara yol açabilmektedir. Covid 19 virüsü kısa sürede ortaya çıkmış, dünyadaki ülkelere yayılarak pandemi haline dönüşmüştür. Hastalığa yakalanan kişi sayısındaki hızlı artış, 
beraberinde hastalık ve salgına yönelik üretilen aşırı bilgi yoğunluğunu ve asılsız haberleri de beraberinde getirmiştir. Özellikle insanların kendilerini tehlikede hissetmeleri ve hastalık ilgili her noktanın henüz aydınlanmamış olması, duygu paylaşımlarında artışa, manipülasyonlara ve söylentilere daha açık bir ortama yaratmaktadır. Bilgi çağında bu tip bilgilerin ya da paylaşımların, sosyal ağlar yoluyla yapılması, virüsün yayılması kadar hızlı ve kolay olabilmektedir. Bu dönemde sosyal medyanın adeta bir şekilde kolektif bir üzüntü ya da endişe alanı haline geldiği de gözlemlenmiştir. Karantinada sıkışmış kalmış insanların hikayeleri, tedavi sürecinin ne kadar ağır olduğunu paylaşan hastaların korku yaratan ifadeleri sıklıkla sosyal medyada yer bulmuştur (Hao, Basu:2020). Covid 19 döneminde üretilen yalan haberler genel olarak üç başlık altında toplanabilmektedir. Birincisi, hastalıktan korunma yollarıyla ilgili olarak paylaşılan, sarımsak yemek ya da çok sıcak su içmek gibi asılsız tavsiyelerdir. İkincisi virüsün kaynağı ve yayılımı ile ilgili asılsız bilgilerdir. 5G teknolojisinin virüse sebep olabildiği ya da Türklerin genetik yapısı dolayısıyla bu hastalıktan etkilenmeyecekleri gibi spekülatif haberler bu başlık altında toplanabilmektedir. Üçüncü ve son aşamada ise virüsün dünyanın farklı bölgelerinde yarattığı kaotik duruma yönelik servis edilen bilgiler akla gelmektedir.

İnsanlar genellikle politikacı ya da gazeteci olmadıkları için, gündemi belirleyen haber ve bilgi paylaşımlarında etkilerinin çok olmadıklarını düşünmektedirler. Oysaki, "trend" olan "hashtag"ler göstermektedir ki, sosyal medyadaki takipçi sayınız az olsa dahi, paylaşımlarınız dikkat çekici olabilmekte ve hızla yayılabilmektedir. Infodemi tehdidinin etkisini arttırma riskinde bu gerçeğin göz ardı edilmesinin payı büyüktür. Çevrim içi varlığınızı, ne kadar az takipçiniz olursa olsun, önemsizmiş gibi davranmak tehlikeli olabilmektedir (Ohlheiser: 2020). Uzmanlar bir haber paylaşımı yapmadan önce haberi farklı şekillerde doğrulatabileceğimizi belirtmektedir. Örneğin, Uluslararası Doğrulama A $\breve{g}$, bu konuda başvurulabilecek kaynaklar arasında sayılmaktadır. Ayrıca bilgilerin doğrulaması aşamasında "Google Photos" ya da "Botometer" gibi uygulamaların da kullanılabileceği tavsiye edilebilmektedir.

Bir salgın sırasında, bilgi sistemleri de en az tıbbi sistemler kadar kritik rol oynamaktadır. Bir anlamda bilgi sistemleri pandeminin kilit noktalarından biridir. Pandemi görüldüğünde verilerin ve diğer bilgilerin durumun gerektirdiği hızda yönetilmesi kritik bir durumdur. En bilinçli kararların alınması, eyleme geçilmesi ve sağlık ile ilgili en doğru istihbaratın sağlanıp ona göre politikalar benimsenmesi için gerekli verilerin sağlanması gerekmektedir. Gelişen teknolojiler ve otomasyon, insanlık tarihinde daha önce hiç olmadığı kadar detaylı bilginin toplanabilmesine ve işlenmesine imkân tanımaktadır. $\mathrm{Bu}$ durum halk sağlığını geliştirme adına büyük bir potansiyeli barındırmaktadır. Günümüzde teknolojinin ulaştığ 1 yüksek birikimle birlikte bilgi sistemleri anlık, hızlı ve koordineli veri erişimi ve paylaşımı sağlayabilmektedir. Ancak güvenlik açığı en dikkat edilmesi gereken hususlarda baş sıraya yerleşmiştir. Doğru bir şekilde ayrıştırılmış sağlık verileriyle tüm bakım düzeylerinde potansiyel sağlık eşitsizliklerini azaltan eylemler planlamak mümkündür.

\section{Türkiye'den İnfodemi Örnekleri}

Halk sağlığı açısından acil bir vaka durumunun ortaya çıkmasının ardından bunun etkisi ülkeleri ve toplulukları ekonomik, sosyal, psikolojik olarak etkileyip (WHO 2019) yayıldıkça, güvenilir bir kaynaktan doğru bilgiyi sağlamanın önemi daha da anlaşılmaktadır. Türkiye'de koronovirüs vakasının ilk olarak tespit edildiği 11 Mart 2020 tarihinden itibaren yöneticiler bilgi kirliliğinin önüne geçebilmek adına günlük raporlama ile mevcut durumu topluma aktarmışlardır. Ancak dünyanın birçok ülkesinde olduğu gibi Türkiye'de bazı bilimsel olmayan yöntemlerle hastalıktan korunulabileceği söylentileri artmış ve bu tip yanlış yöntemleri uygulayanların haberleri de basına yansımıştır. Çalışmamız, infodemi kavramı çerçevesinde, sosyal medya üzerinden paylaşılan ve bir anda gündem oluşturan, kaynağı çoğu zaman belirsiz olan ve bilimsel verilere dayanmayan bilgi akışından bazı örneklerle de desteklenmiştir. Türkiye'de tuzlu suyla gargara 
yapmak, bitkisel çözüm aramak ve hatta hatta çamaşır suyu içmek gibi sınırları zorlayan dezenformatif bilgiye dayalı uygulamalara rastlanmıştır.

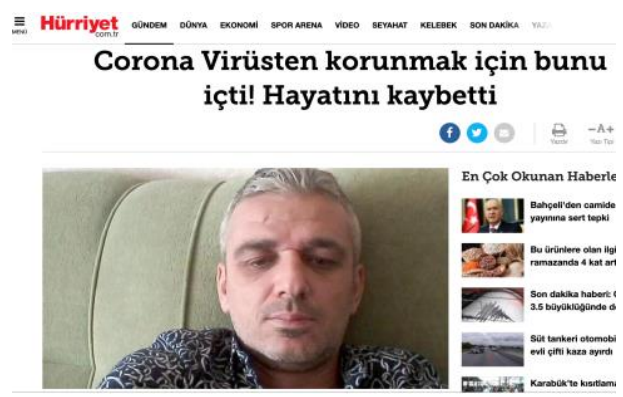

Resim 1: "Coronovirüsten korunmak için bunu içti, hayatını kaybetti" başlıklı haber

Kaynak: Hürriyet Gazetesi, 24 Mart 2020, https://www.hurriyet.com.tr/gundem/corona-virustenkorunmak-icin-bunu-icti-hayatini-kaybetti-41503783

Hürriyet gazetesinden Onur Kaya'nın 26 Nisan 2020 tarihinde aktardığı habere göre, Tekirdağ'ın Çerkezköy ilçesinde yaşadığı belirtilen Barış Çimen'in Corona Virüs salgınından korunmak için dezenfektan ve etil alkol içtiği iddia edilmiştir. Çimen, kaldırıldığı hastanede hayatını kaybetmiştir.

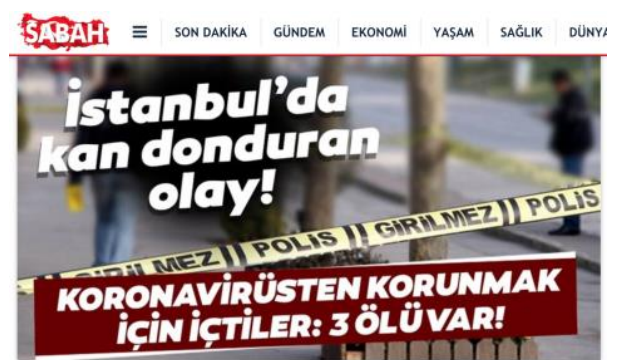

Resim 2: "Koronavirüsden korunmak için içtiler: 3 ölü var" başlıklı haber

Kaynak 2: Sabah Gazetesi, 18 Mart 2020, https://www.sabah.com.tr/yasam/2020/03/18/istanbuldadehsete-dusuren-olay-corona-virusunden-korunmak-icin-ictiler-3-olu

Sabah gazetesinde 18 Mart tarihinde servis edilen haberin başlı̆̆ı, "İstanbul'da kan donduran olay! Koronovirüsten Korunmak İçin İçtiler: 3 Ölü Var!” şeklindedir. Haberin detaylarında İstanbul'da yaşanan sahte alkolden ölüm vakasının ayrıntılarının şok edici olduğu ve yanlış bilginin etkisiyle koronavirüsten korunmak için sahte alkol alan üç kişinin yaşamını yitirdiği yer almaktadır. Haberde ayrıca, yine mart ayında İran'da koronavirüs salgınından korunmak için sahte alkol alan çok sayıda kişinin öldüğünün de altı çizilmiştir.

Türkiye'deki tanınmış medyatik doktorların bazılarının da koronovirüs konusundaki açıklamaları doğruluğu kanıtlanamayan iddialar boyutunda kalmıştır. Bu iddialardan bir tanesi Türklerin genetik yapıları dolayısıyla bu virüse karşı daha dirençli oldukları yönündeyken (Yeniçağ Gazetesi, 2020) bir diğeri, kelle paça yiyerek bağışıklık sistemimizi çok güçlendireceğimiz ve böylece bu hastalığa karşı korunacağımız yönündeydi (Hürriyet Gazetesi 2020). Oysaki gribe ve virüslere karşı direnç sağladığına inanılan bu yemek hakkında Dünya Sağlık Örgütü'nün resmi bir araştırması bulunmamaktadır. Genetik yapılarımız sebebiyle hastalığa yakalanmayacağımız iddiası ise hastalığa yakalanıp yaşamını yitiren Türk bireylerden sonra gündemden düşmüştür. Türkiye'de şahit olduğumuz bir başka haber de yine medyatik bir doktorun, çocuklara bu virüsün bulaşmayacağ 1 iddiası üzerine kurgulanmıştır. Hatta bu sebeple okulların tatil edilmemesi gerektiğine kadar 
tartışmalar yapılmıştır. Daha sonrasında virüsün çocuklara da bulaşabildiği hatta dünyada 12-18 yaş arası bazı vakalarda çocukların da yaşamını yitirebildiği görülmüştür.

\section{Bulgular}

Türkiye'de infodemi konusundaki farkındalığa yönelik yapmış olduğumuz ankete 366 kişi katılmıştır. Ankete katılanların \%48,4'ü erkek iken \%58,6'sı kadındır. Çalışmaya katılan kişilerin $\% 48,6$ 'sı 45-60 yaş arasında olup cevaplayanlar arasında ağırlıklı kesimi oluştururken onları \%26,8 ile 35-45 yaş arasındaki bireyler takip etmiştir.

\section{Yaşınız}

366 responses

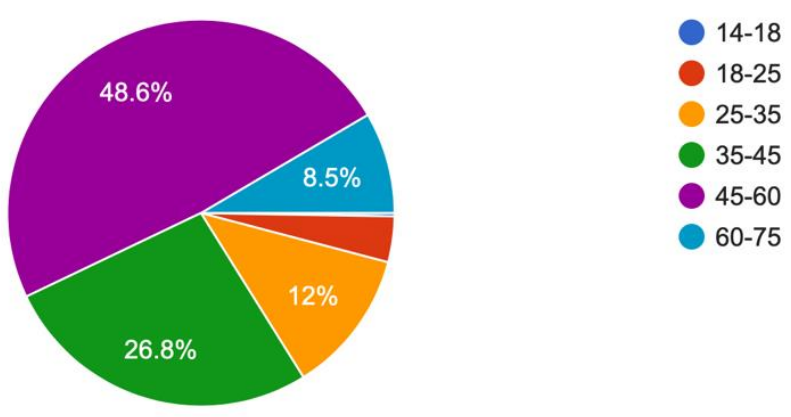

Tablo 1: Katılımcıların yaş dağılımı grafiği

Katılımcıların \%52,7'si üniversite mezunu olarak çoğunluğu temsil ederken, onları \%\%19,9 ile lise mezunları ve \%18,6 ile yüksek lisans mezunları izlemektedir. \%8,7 ile de doktora derecesi olan kişiler ankete katkıda bulunmuştur. Genel olarak ankete katılanların eğitim durumu tablosunu incelediğimizde, her eğitim seviyesinin Türkiye'deki genel eğitim durumuna yakın bir şekilde temsil edildiği anlaşılmaktadır.

\section{Eğitim Durumu}

366 responses
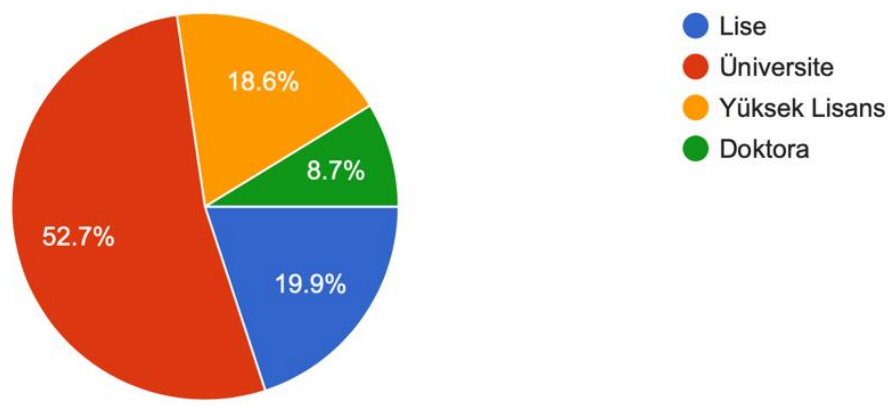

Tablo 2: Katılımc1ları eğitim durumu grafiği

Çalışmaya katılan kişilerin dünya ve Türkiye'deki gelişmeleri sırasıyla sosyal medya, televizyon kanalları ve online haber içeriklerinden elde ettiği anlaşılmıştır. Her gün ilerletilen ve 
genişletilen uygulama alanları ile internet, medya dönüşüm çağı için mükemmel bir araçtır (Andrejevic, 2014: 64). Haber alma alışkanlıklarımızın sosyal medya alanına kaymış olması, sunduğu hız ve kolaylık sebebiyle oldukça beklenilir bir durumdur. Gündemi takip ederken geçmişte ilk sıralarda kendisine yer bulan yazılı basının, günümüzde oldukça gerilediği dikkat çekicidir. Howe'a göre (2006), dijital medya ile birlikte bloglar birleşmiştir. Oluşan interaktif yapı içinde okuyucuların yorumları için alanlar açılmış ve genel olarak halkın haberleri paylaşması ve haberlere katkıda bulunması için birçok yeni yol bulunmuştur. Bu da kitlelerin dijital medyaya yönelimini sağlamıştır.

Dünya ve Türkiye'deki olay ve gelişmelerle ilgili haberleri ağırlıklı olarak nereden takip edersiniz? 366 responses

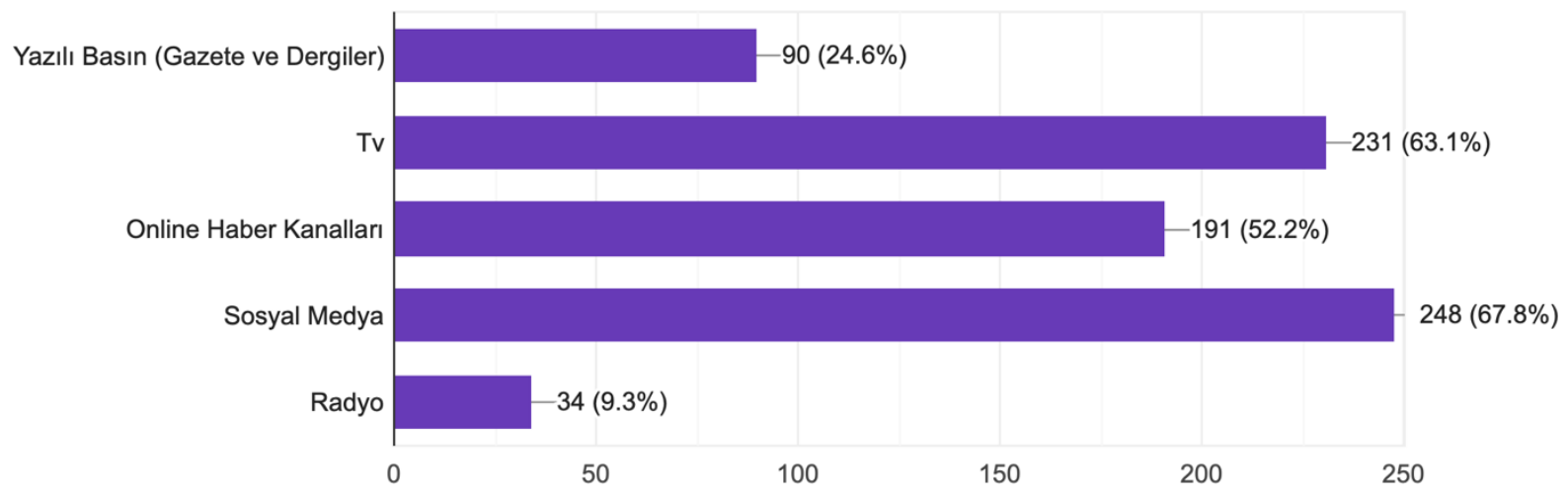

Tablo 3: Katılımcıların gündemi takip ettiği platformlar

Enformasyon dönüşümünün bu kadar arttığı "bilgi çağı" döneminde aynı zamanda yalan haber olgusunun bu denli artması derin bir çelişkidir. Bilgi ve iletişim çağında yaşamamıza karşın iletişim konusunda geçmişte olmadığ 1 kadar çalışma yapılması, iletişimsel sıkıntı ve engellerin araştırılması dikkat çekmektedir (Sarıoğlu, 2020: 378). Araştırma sonuçları göstermektedir ki gerçeği arayışın arttığı bu dönemde bireyler haber alma kaynaklarının tercihleri anlamında ana akım medyay $\% 43,6$ oranında takip etmektedirler. Alternatif medya ve sosyal medyayı takip etme oranları ise birbirine çok yakındır. Çalışma ayrıca, katılımcıların bir kısmının hem ana akım medyanın hem de alternatif yayın yapan sitelerin yanlı yayın yaptıklarına inandıklarını ortaya koymuştur. A $\breve{g}$ toplumunun oluşturduğu yeni dünya düzeninde insanların haber ve bilgiye erişimleri de farklı bir boyut kazanmıştır. Özellikle sosyal medya araçlarının popülerliğinin artmasıyla insanlar geleneksel haber medya alışkanlıklarından bu platformlara yönelmişlerdir. Günümüzde hem bireyler hem de kurumlar eskinin geleneksel haber medyası yerine haber üretimi ve tüketimi için sosyal medyaya doğru kaymışlardır. Bu durum gerçek dışı haberlerin çabuk yayılımı gibi olumsuzluklar barındırsa da teyid mekanizmaları gibi çözümleri de kendi içinde barındırmaktadır. Çalışmamızın bu bölümünde verilen yanıtlar dikkat çekicidir. Özellikle son 20 yıl içinde gelişen teknolojiyle birlikte alternatif medya her geçen gün büyümeye devam etmiştir. Araştırmadaki istatistiklerde en fazla güvenilen haber kaynakları olarak yerini alan alternatif medyadaki bu yükselişte internetin sağladığı sınırsız olanaklar büyük rol oynamıştır. İnternetin sağladığı özgürlük ortamı, daha geniş bir yelpazede çok daha geniş bir görüş ve gerçeğin görülmesine ve duyulmasına izin vermiştir. Burada alternatif medya adından da anlaşılacağı gibi ana akım medyaya da bir yerde muhalefet edebilmektedir (Dowmunt ve Coyer, 2007, s. 1). Böylece toplumda kökleşmiş statükocu yapıda değişim, istek ve beklentilerin yoğunlaşması ve çalışmamızda ortaya çıkan verilerle alternatif medyanın geleneksel medya karşısında prestijli bir noktaya ulaşması gerçeği sonucuna varilmaktadir. 
Aşağıdaki haber kaynaklarını hangisini güvenilir bulursunuz?

366 responses

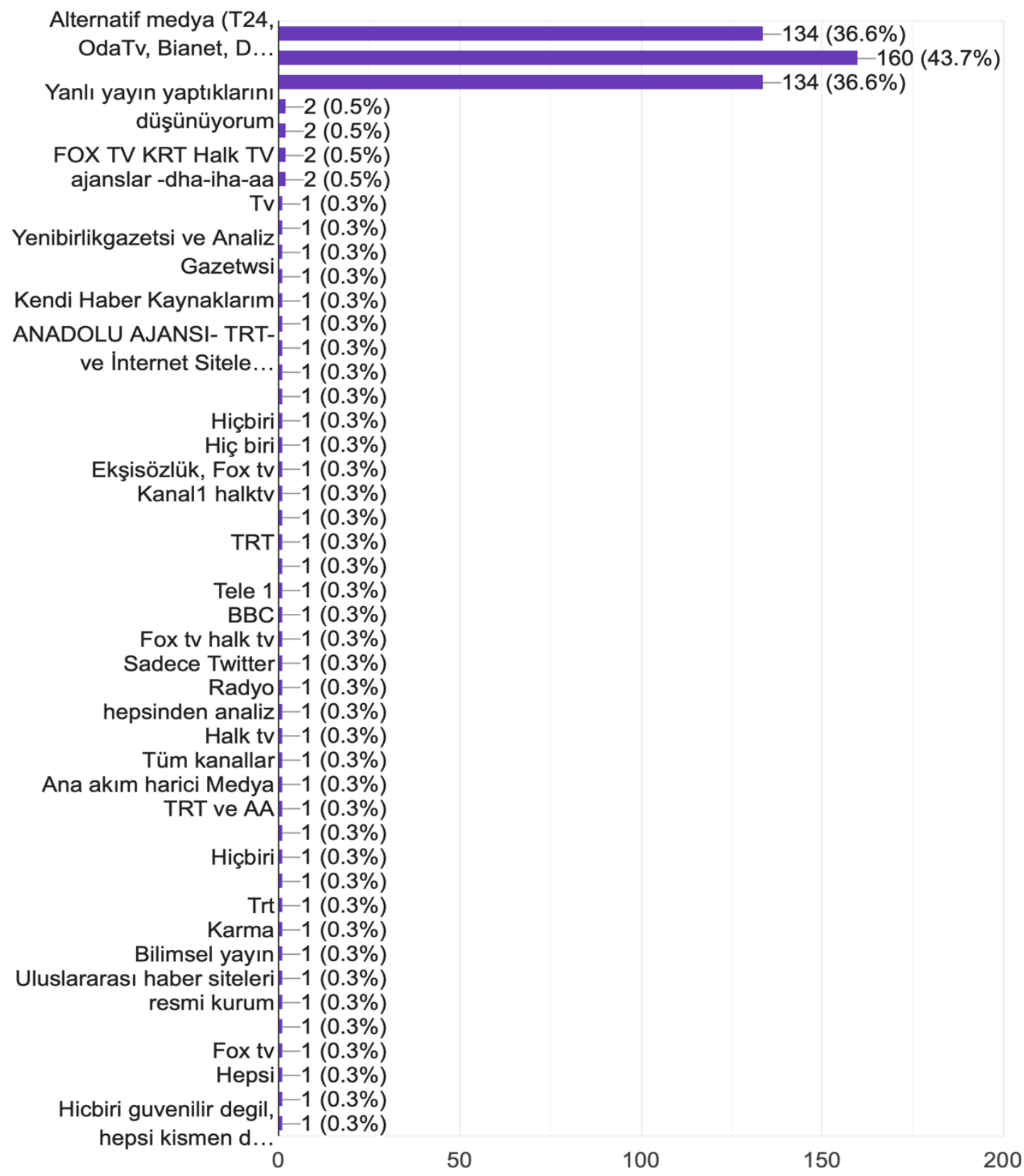

Tablo 4: Katılımcıların güvendiği haber kaynakları 


\section{Sosyal medyada günde ortalama kaç saat vakit geçirmektesiniz? \\ 366 responses}

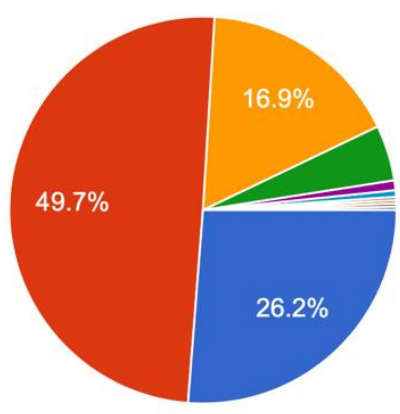

1 saat ve daha az
2-3 Saat
4-5 saat
6-7 saat
8 saat ve daha fazlası
Sosyal Medya kullanmıyorum
Haber Paylaşımları dışında sosyal me...
Bazen 0 bazen bana gönderilen mesa...

$1 / 2$

Tablo 5: Katılımcıların sosyal medyada günlük olarak geçirdikleri süre

$\mathrm{Bu}$ araştırmanın en dikkat çekici sonuçlarından bir tanesi de katılımcılara yöneltilen "Sosyal medya sizin için ne ifade ediyor?" sorusuna \%51,1 oranında "Olmasa da olur." şeklinde yanıt verilmesidir. Sosyal medyaya ve özellikle de sosyal medyaya ulaşmak için en yoğun kullandığımız teknolojik cihazlara bağımlılığımızın bu kadar arttığı bir dönemde, katılımcıların neredeyse yarısının "Olmasa da olur." cevabını vermesi dikkat çekicidir. Günlük rutinimizde ise günde ortalama 47 dakikada bir cep telefonumuzu kontrol ettiğimiz ve $2617 \mathrm{kez}$ tıkladığımıza dair çalışmalar bulunmaktadır (Bankmycell, 2019). 2019 yılında yürüttüğümüz bir başka çalışmada, Türkiye'de Z Kuşağında nomofobinin (akı1lı cep telefonuna bağımlılık) düşük seviyelerde olduğu tespit edilmiştir. $\mathrm{Bu}$ sonuç, bir açıdan katılımcıların konu ile ilgili farkındalıklarının düşük olabileceğini işaret ettiği şeklinde yorumlanabilmektedir. Bir diğer açıdan ise Z Kuşağının teknolojinin içine doğan bir kuşak olması sebebiyle teknolojik aletlerle geçireceği zamanı yönetme konusunda daha bilinçli bir nesil olacağı şeklinde de yorumlanmıştır. Ayrıca bahsi geçen çalışmada, kadın kullanıcıların özellikle sosyalleşme-haberleşme ihtiyaçlarını karşılamak için sosyal medyayı sıklıkla kullanıyor olmaları, nomofobi seviyelerine de yansımaktadır. Kadın katılımcıların nomofobi seviyesi erkek katılımcılara göre daha yüksek ölçümlenmiştir (Sarığlu, 2019:925). Cep telefonunun dış dünya ile ilişkimizi nasıl şekillendirdiği infodemi konulu araştırmamıza da yansımışır. Katılımcıların büyük çoğunluğunun (\%97 oranında) sosyal medyaya akıllı cep telefonları ile eriştiği yansımıştır.

\section{Sosyal medya araçlarına daha çok hangi tür cihazlar ile ulaşmaktasınız?}

367 responses

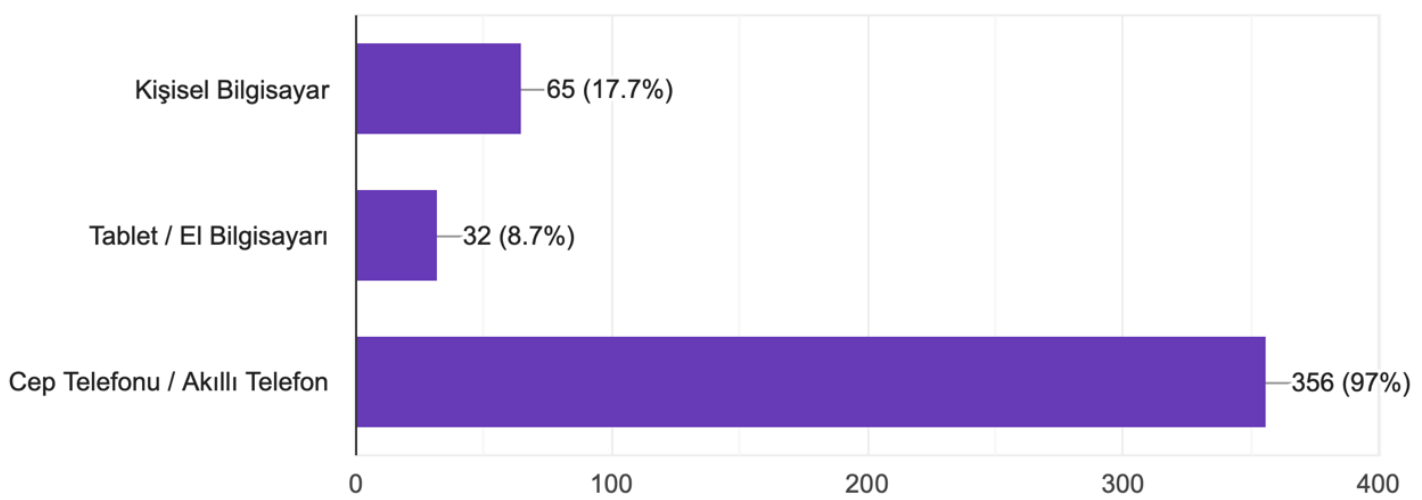

Tablo 6: Katılımcıların sosyal medyaya ulaştığı cihazların dağılımı 
Katılımcılardan 227 kişi sosyal medyada en çok toplumsal konularda paylaşım yaptığını belirtmiştir. Toplumsal konuları sırasıyla eğitim, çevre ve siyaset konuları izlemektedir. Haber bültenlerinin genel akışında ağırlıklı olarak günlük siyasi olayların ağırlıklı yer aldığını düşünürsek katılımcıların sosyal medyadaki paylaşımlarının farklı ağırlıkta olması dikkat çekicidir.

\section{Sosyal medyada en çok hangi konuda haber/bilgi paylaşımları yaparsınız?}

366 responses

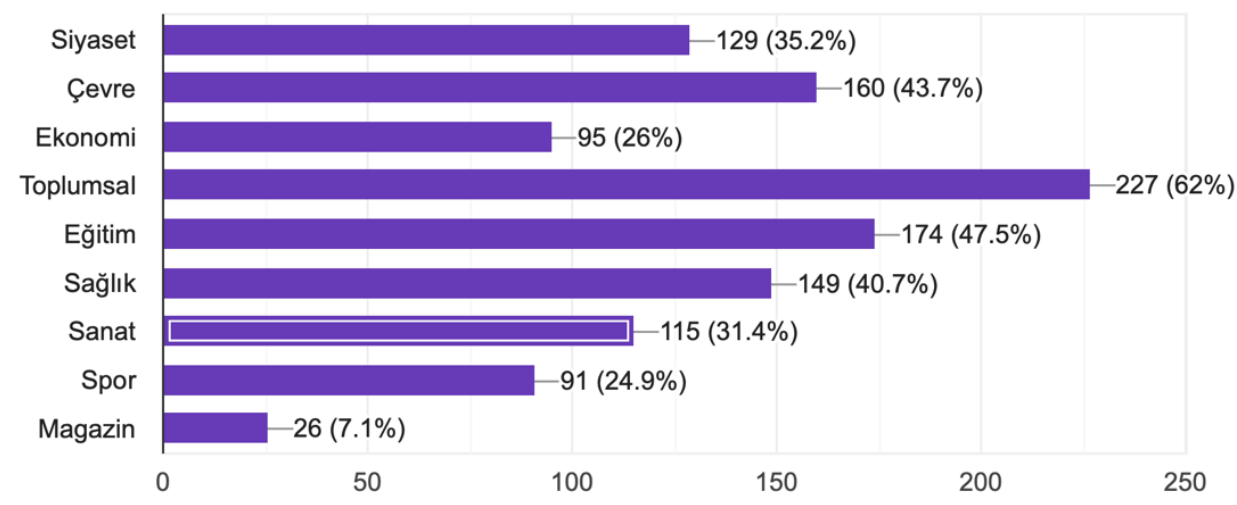

Tablo 7: Katılımcıların sosyal medyada en çok bilgi paylaşımı yaptıkları konular

Sosyal medyada haberi paylaşırken doğruluğunu teyid eder misiniz?

363 responses
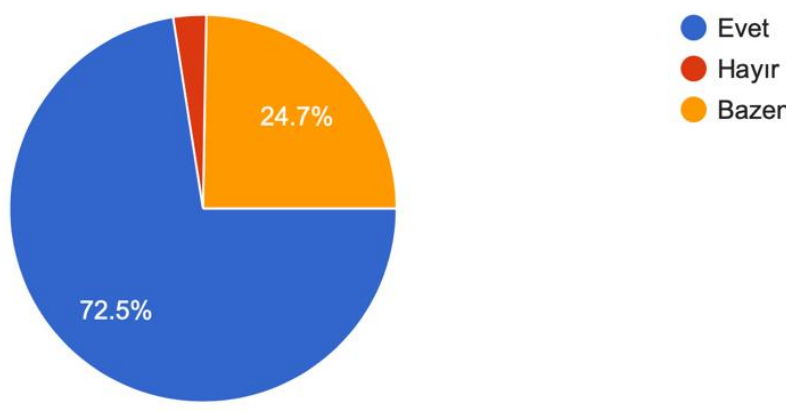

Tablo 8: Katılımcıların sosyal medyada haber paylaşırken haberi teyid etme oranları

Çalışmamıza katılanlara yönelttiğimiz "Sosyal medyada haberi paylaşırken doğruluğunu teyit eder misiniz?" sorusuna 265 kişi evet, 90 kişi bazen, 10 kişi ise hayır cevabını vermiştir. Evet cevabının \% 72,5 gibi yüksek bir seviyede çıkmış olması olumlu bir gelişme olmakla birlikte, sosyal medyada dönüşüm içerisinde olan yalan haberlerin fazlalığını düşündüğümüzde yalan haberlerin yayılımını önlemek için bireylerin haberleri teyit etme konusunda medya okur-yazarlıklarını arttırmalarının faydalı olabileceği anlaşılmıştır. 
Infodemik bir bilgiyi yaydığınızı hiç farkettiniz mi? (Bilinçli ya da Bilinçsiz Bir Şekilde Asılsız Bir Haberi Paylaştınız mı hiç?)

364 responses

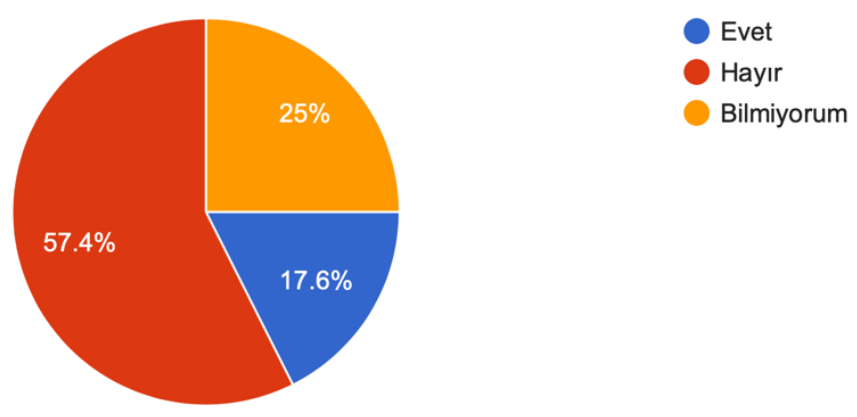

Tablo 9: Katılımcıların infodemik bilginin yayılması konusunda farkındalıkları

Infodemik bilginin yayılmasında cinsiyet farkı olduğunu düşünüyor musunuz?

366 responses

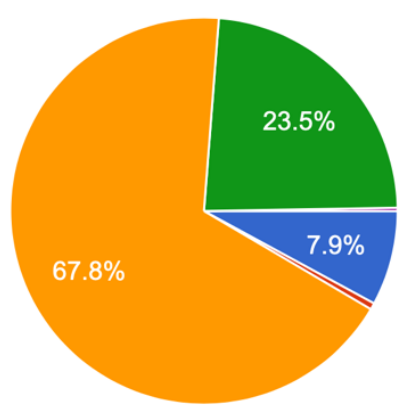

Evet, Infodemik Bilginin Yayılımında Kadınların Daha Çok Sorumlu Olduğunu Düşünüyorum

Evet, Infodemik Bilginin Yayılımında Erkeklerin Daha Çok Sorumlu Olduğunu Düşünüyorum

Bu konuda cinsiyet farkı olduğuna inanmiyorum

Fikrim yok

infodemik bilgi ne demek bilmiyorum

Tablo 10: İnfodemik bilginin yayılmasında cinsiyet fark1 
Sizce, eğitim seviyesi arttıkça infodemik haber paylaşımı azalıyor mu?

365 responses

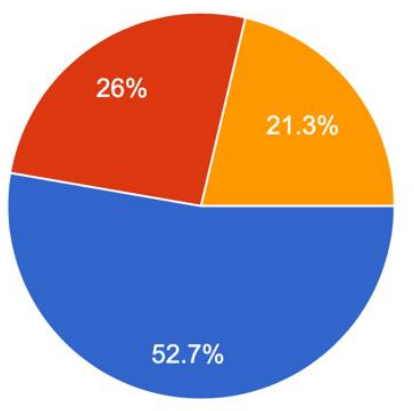

Evet

Hayır

Fikrim Yok

Tablo 11: İnfodemik bilginin yayılması ile eğitim seviyesi arasındaki ilişki

Infodeminin en çok beslendiği kanal sizce hangisidir?

363 responses

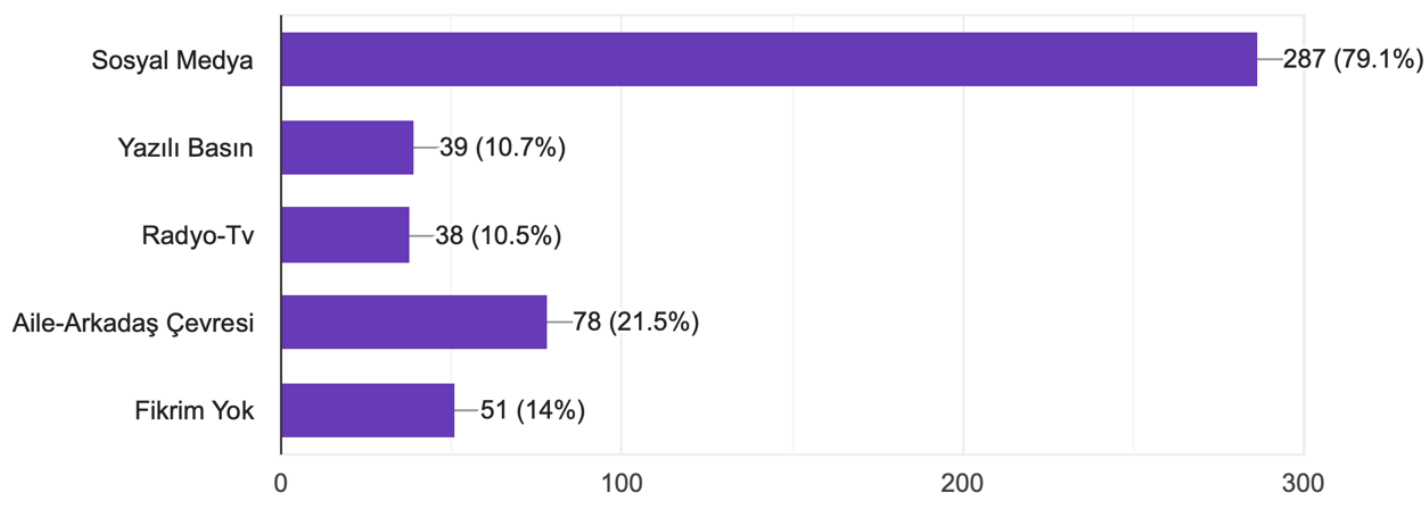

Tablo 12: İnfodemik bilginin beslendiği kanallar 
Infodemik bilginin sosyal medya kanallarında en çok nerede yayıldığını düşünüyorsunuz?

353 responses

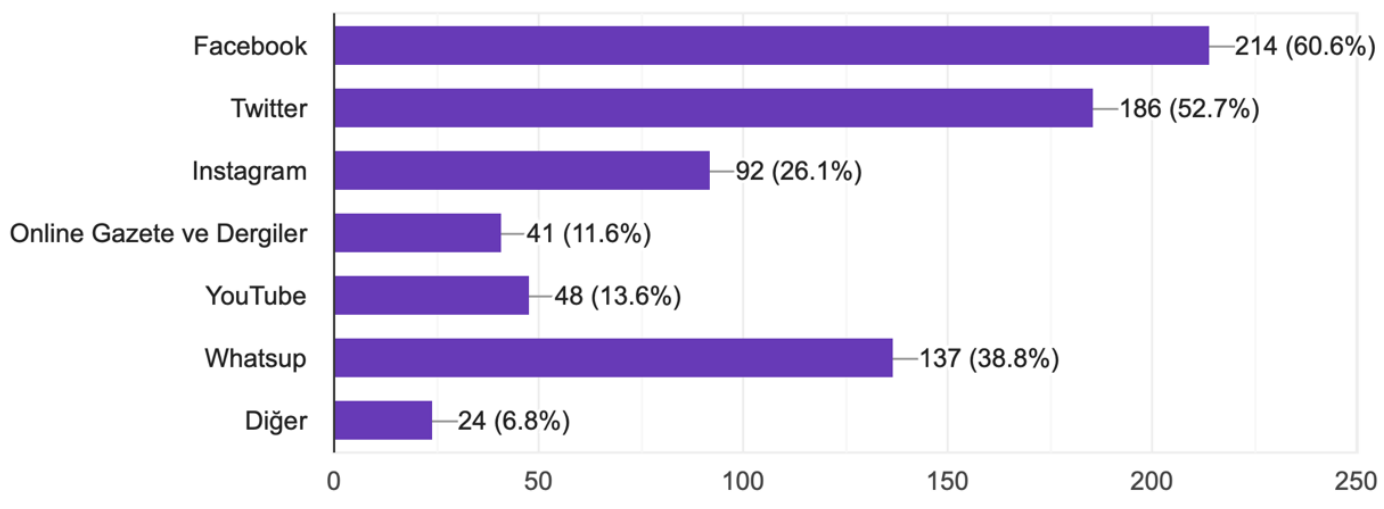

Tablo 13: İnfodemik bilginin yayıldı̆̆ı sosyal medya kanalları

Sosyal medyada infodemik bilginin dağılımı konusunda ankete katılanların büyük bir kısmı ilk sıraya Facebook'u yerleştirmiştir. Facebook'u sırasıyla, Twitter, Whatsup ve Instagram takip etmektedir. Facebook'un son dönemde yalan haberlere karşı aldığını belirttiği önlemlere karşın ilk sırada yer alması dikkat çekmektedir. Geleneksel görsel, işitsel ve basılı medyanın çevrimiçi portallara hızlı dönüşümü ve açılan yeni web siteleri, son çeyrek yüzyılda yeni bir trend haline gelmiştir. Bir yandan, sosyal medya, haber üretimi ve yayılması konusunda bir firsat eşitliği sağlarken öte yandan asılsız ve yalan haberler için de bir üreme alanı haline gelmiştir.

\section{Covid konusunda haber almak için en güvendiğiniz kaynak hangisidir?}

366 responses

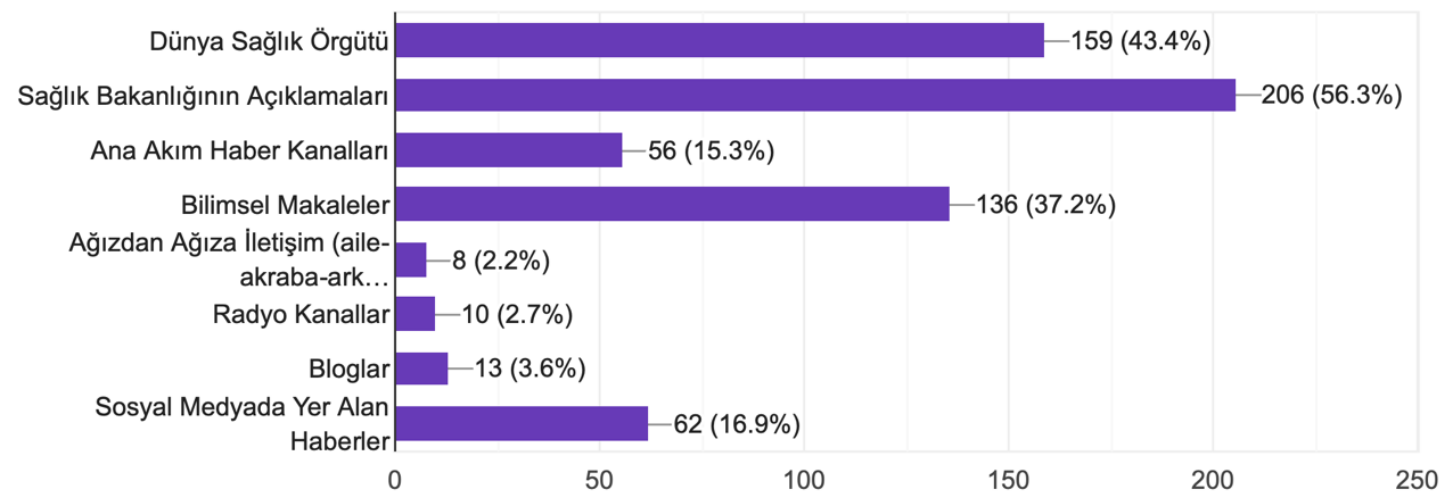

Tablo 14: Katılımcıların Covid-19 konusunda haber almak için en güvendiği haber kaynakları

Katılımcıların Covid konusunda en çok Sağlık Bakanlığımızın açıklamalarına güvendikleri anlaşılmıştır. Bunu takiben, Dünya Sağlı Örgütünün açıklamalarının da büyük bir oranda güven oluşturduğu anlaşılmaktadır. Çalışmada Covid konusunda ana akım haber kanallarına duyduğu güven \%15.3 ile oldukça gerilerde yer alırken ankete katılanların diğer güven duyduğu kaynakların 
bilimsel makaleler olduğu görülmüştür. Yine tablo 14 'te görüldüğü üzere katılımcıların Covid konusunda sosyal medyadaki haberlere duydukları güven de oldukça kısıtlı düzeydedir.

\section{Covid19 ile ilgili en çok karşılaştığınız yalan haber hangi konudadır? 366 responses}

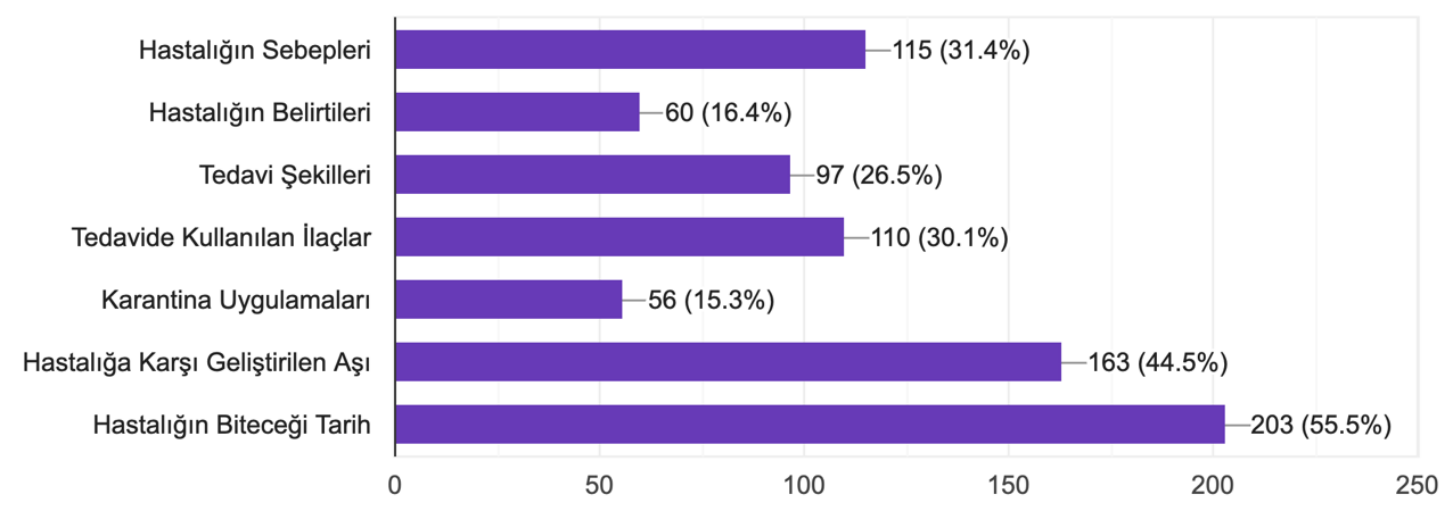

Tablo 15: Katılımcıların Covid-19 konusunda en çok karşılaştıkları yalan haber konu başlı̆g 1

Çalışmamıza katılan 366 kişiden 203 tanesi, Covid-19 konusunda hastalığın bitiş tarihi ile ilgili yalan haber ile karşılaştıklarını belirtmişlerdir Hastalığa karşı aşı geliştirilmesi konusunda da yalan haberlerin dolaşımda olduğu anlaşılmıştır. Hastalığın sebepleri ve tedavisinde kullanılan ilaçlar konusunda da yalan haberlerin yoğun bir şekilde katılımcıların önüne geldiği gözlemlenmiştir.

\section{Sonuç}

Dünya ilk olarak Aralık 2019'da Çin'in Vuhan kentinde tespit edilen ve küresel çapta bir salgına dönüşen Covid-19 adı verilen viral enfeksiyon hakkında her geçen gün daha çok bilgi edinme çabası içerisindedir. Koronovirüs salgını nedeniyle insanların sosyal hayatı, yakın ilişkileri, ekonomik hayatı olumsuz yönde etkilenmiş, yaşam rutinleri değişmiştir. Salgın riski insanlarda korku kayg1, öfke gibi olumsuz duyguları tetiklemiştir (Hatun, Dicle, Demirci, 2020: 531-554). Bu duygusal olumsuzluklar içerisinde insanların birinci önceliği doğru habere ulaşmak olmuştur. Salgının başlarında ağırlıklı olarak hastalığın sebepleri, genetik yapısı ve belirtileri üzerine araştırmalar yapılırken akabinde tedavi yöntemleri ve korunma yöntemleri ile devam etmiştir. Halen bu konularda yoğun araştırmalar sürmekteyken Dünya Sağlık Örgütü Covid-19 ile bağlantılı yeni bir tehditin daha olduğunu öne sürmüştür. Dünyay1 etkileyen bu yeni tehlike Infodemi olarak tanımlanmıştır. Viral olarak yayılan yanlış bilgilendirmenin, halk sağlığını küresel anlamda kötü etkilemesinden endişelenilmektedir. Bir yandan sosyal medya, dünyada salgının güncel durumu ve halk sağlı̆̆ 1 konusunda eğitici bilgilerin paylaşılması konusunda çok yardımcı bir platformdur. Öte yandan ise sosyal medya, yalan ya da asılsız haberlerin defalarca "re-tweet" lenebildiği (tekrardan paylaşıma sokulduğu), gerçeklerin yalan ya da uydurma haberlerin çok gerisinde kalabildiği bir dünya olabilme kapasitesi olduğunu bizlere göstermiştir. Infodemi kavramı, Covid-19 ile gündeme taşınmış olsa da özellikle sosyal medyanın hızlı ve kolay etkileşimi sayesinde yaşamamızdaki pek çok konu ile kesiştiği görülmektedir. Bu çalışmada öncelikle "kavram olarak infodemi" ve "infodemik bilginin oluşumunda sosyal medyanın rolü konusundaki farkındalığımız" irdelenmiştir.

Covid-19 salgının yayılımı arttıkça, çoğumuzun sadece haberleri takip etmeye çalıştığı, bilgi paylaşımlarının ve salgınla ilgili teorilerin havada uçuştuğu bir dönem yaşanmıştır. Haberler kötüleştikçe, asılsız haber paylaşımlarının da artışa geçmesi başta Dünya Sağlık Örgütü olmak üzere 
pek çok kurumu endişelendirmiştir. Koronovirüsü, SARS ve MERS gibi diğer büyük salgınlardan ayıran en önemli noktalardan bir tanesi, dezenformasyonun yayılımın hızının sosyal medya sayesinde çok ileri boyuta taşınmış olması ve konunun infodemi olarak kategorize edilmiş olmasıdır. Aşırı bilgi dolaşımının yanı sıra asılsız/yalan haberlerin yüksek yayılım hızı, insanlarda kaygı, belirsizlik gibi duyguları arttırarak salgınla mücadelede negatif etkilerin oluşmasına sebep olmuştur. Doğru olmayan ya da doğruluğu konusunda belirsizlik bulunan haber içerikleri, taşıdıkları konular, bu haberlerin yayınlandığı medya organları ve yeni medya platformlarındaki yayılım süreçleri birbirinden farklıdır. Gerçek dışı haberler her zaman gerçek olarak kabul edilmese bile kafa karışıklığı yaratması ve tartışma konusu olması da dolayısıyla gündemde önemli rol oynayabilmektedir. Örneğin, salgının başlarında maske takmanın zorunlu olmadığı yönündeki görüşler ağır basarken, vaka sayısı ve hastalığın yayıldığı bölge arttıkça maskenin pek çok ülkede zorunlu hale getirildiği gözlemlenmiştir. Şimdilerde ise maskenin virüs taşıyanların diğer insanlara yaymaması için zorunlu olduğu ama maskenin sağlıklı bireyleri koruma faktörünün düşük olduğu konusunda görüşler belirtilmektedir. Doğruluğu konusunda kesin bir delil olmadan yayılan spekülatif haberlere örnek olarak bu hastalığın sadece yaşlıları etkilediği ve sadece onlar için ölümcül olabildiği haberleri de hatırlanabilmektedir (Devlin, 2020).

İnfodemi kavramının Dünya Sağlı Örgütü tarafından Covid-19 salgınının kendisi kadar üzerinde durulması gereken bir sorun olarak nitelendirilmesi, bu konunun öneminin altını çizmiştir. Yalan ya da asılsız haberlerin, gerçek dışı bilgilerin yönlendirilmesinin ya da dezenformasyonun infodemik bir şekilde yayılım göstermesinin, salgın ile mücadelede en büyük zorluk alanlarından biri olarak önümüze çıkması, bu konunun bilimsel olarak farklı açılardan ele alınması zorunluluğunu doğurmuştur. Çalışmamızda en dikkat çeken noktalardan bir tanesi, katılımcıların yalan haberlerle karşılaştıklarını büyük oranda teyit etmeleridir. Yalan haberin özellikle sosyal medya içerikleriyle birleşerek daha fazla yayılım göstermesi ve normalleşmesi asıl tehlike olarak önümüze çıkmaktadır. Araştırmamızda katılımcıların büyük bir çoğunluğu üniversite mezunu ve daha üst bir eğitim seviyesinde olmasına karşın infodemi kavramının bilinirliğinin sınırlı düzeyde kaldığı anlaşılmıştır. İnfodemik bilginin yayılımında cinsiyet ya da yaşın önemli bir parametre olarak görülmediği ama eğitim seviyesinin belirleyici olduğuna inanıldığı anlaşılmıştır. Yanlış bilgi verme ya da doğru olmayan haberlerin farklı medya organlarından gelse de kitleleri yanıltma ve toplumda sosyal ve psikolojik açıdan tahribat yarattığı gerçeğiyle toplumdaki herkes karşı karşıya kalabilmektedir. Ve bu süreçte yurttaşların bu tehdite karşı duyarlı oldukları da araştırmamıza yansımış olsa da bazen taşıyıcı vasfiyla toplumdaki herkes bu tehditin bir parçası ya da temsilcisi olabilme riskini taşımaktadır.

\section{Kaynakça}

Andrejevic M. (2014). Eleştirel Medya Çalışmaları 2:0 Etkileşimli Bir Üst Sürüm (L. Keskiner, Trans.). M. Çakır (Ed.), Yeni medyaya eleştirel yaklaşımlar, Doğu Kitabevi, İstanbul

Bankmycell (2019). Smartphone Addiction Facts and Phone Usage Statistics, The Definitive Guide 2019 Update, https://www.bankmycell.com/blog/smartphone-addiction/

Cinelli M., Quattrociocchi W. , Galeazzi A., Carlo Michele Valensise C.M. , Emanuele Brugnoli E., Schmidth A. L. , ZolaP., Zollo F. , Scala A. (2020). The Covid-19 Social Media Infodemic, Cornell University, arxiv.org, Social and Information Networks (cs.SI); Adaptation and SelfOrganizing Systems, Physics and Society, arXiv:2003.05004

Chakravorti, B. (2020). As Coronavirus Spreads, So Does Fake News, Bloomberg Opinion, Technology and Ideas, 6 Şubat, https://www.bloomberg.com/opinion/articles/2020-0205/as-coronavirus-spreads-so-does-fake-news 
Devlin H., (2020), Can A Face Mask Protect Me From Coronovirus? Covid 19 Myths Busted, Guardian, 11 Nisan, www.guardian.com

Dowmunt, T., \& Coyer, K. (2007). Introduction. In K. Coyer, T. Dowmunt \& A. Fountain (Eds.), The Alternative Media Handbook (pp. 1-12). New York: Routledge.

Ekman, P. (2009). Telling Lies: Clues to Deceit in the Marketplace, Politics, and Marriage, 9780393337457, Norton

Ireton C., Posetti J. (2018), Journalism, Fake News and Disinformation, Handbook for Journalism Education and Training, Unesco Series On Journalism Education, France

Hao K., Basu T. (2020), The Coronovirus Is The First True Social-Media Infodemic, MIT Technology Review, https://www.technologyreview.com/2020/02/12/844851/thecoronavirus-is-the-first-true-social-media-infodemic/

Hatun, O., Dicle, A. N: \& Demirci, İ. (2020). Koronovirüs salgınının psikolojik yansımaları ve salgınla başa çıkma, Turkish Studies, 15(4), 531-554

Howe, J. (2006). The Rise of Crowdsourcing. Wired, Issue: 14, http://www.wired.com/wired/archive/14.06/crowds.html

Hürriyet Gazetesi, (2020). Coronovirüsten Kurtulmak için Bunu İçti, Hayatını Kaybetti, 24 Mart, https://www.hurriyet.com.tr/gundem/corona-virusten-korunmak-icin-bunu-icti-hayatinikaybetti-41503783

Hürriyet Gazetesi, (2020). Canan Karatay'ın Açıklaması Ortalığı Karıştırdı! Sadece Kelle Paça Virüsten Korumaz, https://www.hurriyet.com.tr/gundem/sadece-kelle-paca-virustenkorumaz-41454556

Kapusta J, Obonya J. Improvement of Misleading and Fake News Classification for Flective Languages by Morphological Group Analysis. In: Informatics. Informatics. (Multidisciplinary Digital Publishing Institute); 2020;7(1):4.

Keyes, R. (2004). The Post-Truth era: Dishonesty and Deception in Contemporary Life. New York, NY, St. Martin's Press.

Kırık A.M., Özkoçak V. (2020). Yeni Dünya Düzeni Bağlamında Sosyal Medya ve Yeni Koronavirüs Pandemisi, Sosyal Bilimler Dergisi, Y11:7 Sayı:45, Nisan, 2149-0821

Koyuncu, H. (2020), Sosyal Medyada Koronovirüs Paylaşımları: Doğru Bilinen 10 Yanlış, Euronews, 3 Mart, https://tr.euronews.com/2020/04/03/sosyal-medyada-koronaviruspaylasimlari-dogru-bilinen-10-yanlis-corona-virus-covid-19

Kulshrestha J, Eslami M., Messias J., Zafar M. B., Ghosh S., Gummadi K. P., Karahalios K.. (2017). Quantifying Search Bias: Investigating sources of Bias For Political Searches In Social Media. In Proceedings of the 2017 ACM Conference on Computer Supported Cooperative Work and Social Computing

Mesquita C.T., Oliveira A., Seixas F. L., Paes A. (2020), Infodemia, Fake News and Medicine: Science and The Quest for Truth, International Journal of Cardiovascular Sciences. https://doi.org/10.36660/ijcs.20200073

Nielsen, R. K., \& Graves, L. (2017). "News you don't believe": Audience perspectives on fake news, https://reutersinstitute.politics.ox.ac.uk/sites/default/files/201710/Nielsen\%26Graves_factsheet_1710v3_FINAL_download.pdf 
Ohlheiser A., (2020). How to Protect Yourself Online From Misinformation Right Now, MIT Technology Review, Humans And Technology, June, https://www.technologyreview.com/2020/06/02/1002505/black-lives-matter-protestmisinformation-advice/

Ozbay FA, Alatas B. Fake news detection within online social media using supervised artificial intelligence algorithms. Phys A Stat Mech its Appl. Feb 2020;540:123174.

Özarslan, M. Z. (2014). Kitleleri Harekete Geçirme Aracı Olarak Sosyal Alg1 Yönetimi. Yüksek Lisans Tezi. İstanbul Ticaret Üniversitesi, Sosyal Bilimler Enstitüsü, Uluslararası İlişkiler.

Rubin VL, Chen Y, Conroy NJ. Deception detection for news: three types of fakes. Proc Assoc Inf Sci Technol. 2015;52(1):1-4.

Sabah Gazetesi, (2020). Koronovirüsten korunmak için içtiler: 3ölü, https://www.sabah.com.tr/yasam/2020/03/18/istanbulda-dehsete-dusuren-olay-coronavirusunden-korunmak-icin-ictiler-3-olu

Sarığlu, E.B. (2019) Türkiye'de Z Kuşağında Görülen Nomofobi Seviyesi: Cinsiyet, Öğrenim Düzeyi ve Sosyo-Ekonomik Değişkenlere Göre Farklılıklar, Journal of Social and Humanities Sciences Research, Vol:6, Iss:35, 914-927

Sarıoğlu E. B. (2020). Yalan Haber, "Post-Truth" Kavramı ve Medya Üçlemesi: Geçmişten Günümüze Gündem Belirleyen Örnekler, ITOBIAD, İnsan ve Toplum Bilimleri Araştırmalanı Dergisi 2147-1185, 9, (1), 377-397

Shu K, Sliva A, Wang S, Tang J, Liu H. Fake news detection on social media: A data mining perspective. ACM SIGKDD Explor Newsl. 2017;19(1):22-36.

Vicario M.D., Bessi A., Zollo F., Petroni F., Scala A. Caldarelli G., Stanley H. E., Quattrociocchi W., (2016). The Spreading of misinformation online, PNAS, Proceedings of the National Academy of Sciences of the United States of America, January 19, 113 (3)

WHO (2019). China Report of the WHO-China Joint Mission on Coronavirus Disease (COVID-19); WHO: Geneva, Switzerland, 2019.

WHO-Munich Security Conference (2020). WHO Director General Speeches Detail, 15 Şubat, https://www.who.int/dg/speeches/detail/munich-security-conference

Yeniçağ Gazetesi, (2020), Oytun Erbaş: "Coronovirüs Türklere Bulaşmıyor", https://www.yenicaggazetesi.com.tr/oytun-erbas-corona-virus-turklere-bulasmiyor270766h.htm

Zarocostas J. (2020). How to Fight an Infodemic, The Lancet, Regional Health, World Report, Vol:395, Iss:10225, Feb 29, https://www.thelancet.com/journals/lancet/article/PIIS01406736(20)30461-X/fulltext 